\title{
Article
}

\section{Reforming the WTO Dispute Settlement Mechanism: Towards a Mega-Multilateral Court?}

\section{Zihan Liu*}

The Dispute Settlement Mechanism of the World Trade Organization (WTO) is facing serious crisis, which has impeded its normal function. To address this impasse, this article suggests a reform of the WTO's dispute-settlement mechanism: the establishment of a new megamultilateral court to substitute for the Appellate Body. The first part of this paper addresses the reasons for considering this approach. The second part identifies how to establish a new mega-multilateral court within the WTO. The third part puts forward an idea of the function of the Dispute Settlement Body, which would serve as a forum for adjudicators and State Parties of the mega-multilateral court, in order to balance judicial independence, judicial accountability, and consistency. In discussing the reason for this reform, approaches to implementing it, and other examples of what form it might take, this article concludes that it is appropriate to establish a new mega-multilateral court within the WTO.

Keywords: WTO Dispute Settlement Mechanism, Appellate Body, Mega-Multilateral Court, Judicial Independence, Judicial Accountability, Judicial Consistency

* Attorney-at-law (PRC Bar). LL.B. (SHUPL), LL.M. (Edinburgh). ORCID: http://www.orcid.org/ 0000-0002-2845-6013. The author may be contacted at: zihanliu980329@gmail.com/Address: EH16 6YL, 37 Double Hedges Park, Edinburgh, UK.

All the websites cited in this article were last visited on February 4, 2021. 


\section{INTRODUCTION}

The Dispute Settlement Mechanism (DSM) of the World Trade Organization (WTO) guarantees that international trade rules are implemented within the global trading community through a clear dispute settlement process between the WTO members. ${ }^{1}$ However, the DSM is in crisis now, due in particular to the blockage by the United States (US) of the Appellate Body (AB) members' appointment. In this regard, there is a need to search for a long-term solution for reforming the DSM to maintain the normal operation of the WTO.

This article aims to introduce the idea of a new mega-multilateral court within the WTO that will serve as an appeal review body ultimately replacing the AB. This paper is divided into five parts including Introduction and Conclusion. Part two will indicate the reasons for establishing a mega-multilateral court: the absence of co-operation from the US; the inherent limitations of the AB; and proposals provided by the WTO members as a "temporary avenue." Part three will discuss the institutional designs of the Dispute Settlement Body (DSB) and the working methods of the proposed mega-multilateral court, including the appointment of adjudicators, the binding decisions of the Assembly of State Parties, and the idea of creating a special chamber. Part four will highlight that the DSB could serve as a forum for the mega-multilateral court and State Parties by creating an annual meeting, and simultaneously balance judicial independence, accountability, and consistency. The DSB would serve as the governing body of the mega-multilateral court, and the institutional dialogues between these two institutions would be essential for maintaining the proposed court's legitimacy.

\section{Why A New Mega-Multilateral Court INSTEAD OF THE AB?}

\section{A. Absence of Co-operation from the US}

The US blocked the appointment of the $\mathrm{AB}$ members and put forward five claims against the $\mathrm{AB}$ that now impede its normal function: 1) members need to resolve the issue of Rule 15 of the working procedures for appellate review as a priority; ${ }^{2}$ 2) $\mathrm{AB}$ reports have been issued beyond the 90-day deadline provided for in Article 
17.5 of the $\mathrm{DSU} ;{ }^{3} 3$ ) certain findings of the $\mathrm{AB}$ have not been necessary to resolve the relevant dispute, and thus have amounted to "advisory opinions" " rather than binding rulings, and a range of $\mathrm{AB}$ interpretations have added to or diminished members' rights under the WTO agreements; ${ }^{5} 4$ ) some AB findings have been superfluous to the resolution of the disputes, and have not fallen under the scope of appellate review under Article 17.6 of the DSU, which indicates that the AB cannot review panel fact findings, including the meaning of municipal law of a member; ${ }^{6}$ and 5) the $\mathrm{AB}$ has introduced a doctrine of binding precedent, whereas there is a legal basis only for prior reports being persuasive for subsequent panels. ${ }^{7}$ These concerns show that Trump administration made no secret of its dissatisfaction with the WTO, and in particular with its dispute-settlement system.

In fact, the objections were initially raised by the Obama administration, in part to block the reappointment of the South Korean member Seung Wha Chang in 2016; the Trump Administration continued to disapprove of the selection of AB members in August 2017. Trump criticized the WTO dispute-settlement mechanism by complaining that the US had lost almost all the cases in the $\mathrm{WTO}^{8}$ and proposed an "America First" perspective. ${ }^{9}$ It is clear that the Trump administration escalated the alleged controversy over the $\mathrm{AB}$ and its functioning to a wholly new level that has already threatened the proper functioning of the WTO dispute-settlement system, and may spell its demise entirely in the somewhat longer term. ${ }^{10}$ Although the view of the Trump administration was not grounded in evidence, it shows that the US was dissatisfied with the $\mathrm{AB}$ and intended to paralyze it. ${ }^{11}$

Although other members of the WTO endorsed a number of proposals - for example, that proposed by Japan, Australia and Chile directly responding to the US claims by clarifying that the AB "shall not review panels' fact-finding, such as the meaning of municipal law, as an issue of law" dissatisfaction with these proposals, and clearly indicated that they would not be accepted. Moreover, Jennifer Hillman said in the 2020 annual conference of the American Society of International Law that the real intention of the US is to kill the $\mathrm{AB},{ }^{13}$ even if these proposals were to cater to the US claims. Although the WTO and its members have accommodated many US demands, it seems impossible to resolve the current crisis by retaining the function of the $\mathrm{AB}$ as it stands, due to US efforts to hinder and disrupt it. 
A dissatisfied member may seek to close a court from the inside, instead of formally exiting the international organization in which it participates. ${ }^{14}$ For example, the US is not seriously considering exiting the WTO. Instead, outside the dispute-settlement context, it has pursued certain initiatives within the WTO, such as strengthening notification requirements under the $\mathrm{WTO},{ }^{15}$ which were designed to shut the $\mathrm{AB}$ down in a narrower sense. ${ }^{16}$ In addition, while the US has continued to block the operation of the $\mathrm{AB}$, it has not provided its own proposals about how to reform it, and has responded unfavorably to the reforms proposed by other members, which aim to address the US grievances by suggesting that: "Members need to engage in a deeper discussion of why the $A B$ has felt free to depart from what members agreed to." ${ }^{17}$ The US practices demonstrate its unwillingness to cooperate and break the log-jam.

The US concerns over the functioning of the $\mathrm{AB}$ did not begin with the election of Donald Trump, and they have not ended until now that he already left office. ${ }^{18}$ It is arguable that the real intention of the US has been hidden behind the language of political statements. It is thus difficult to negotiate and reach a viable agreement to defuse the impasse. If the real interest of the US is to win all of its requirements, trade negotiations may not be successful. In addition, the US may seek to close a court from the inside, instead of formally exiting the international organization itself. Therefore, the AB impasse cannot be broken as long as the US is unwilling to cooperate in resolving it. ${ }^{19}$

\section{B. Limitations of the $A B$}

\section{The 90 -day time limitation}

The WTO's AB is a standing body consisting of seven members whose mandate is to hear appeals from panel cases. While it is a permanent body, the AB members serve on a part-time basis. ${ }^{20}$ However, the $\mathrm{AB}$ has been far busier than originally planned since it opened its doors in $1995 ;{ }^{21}$ for example, 70 percent of panel reports have been appealed in the 2010 $\mathrm{s}^{22}$ three reports in $2010,{ }^{23}$ nine in $2011,{ }^{24}$ five in $2012,{ }^{25}$ two in $2013,{ }^{26} 13$ in $2014,{ }^{27}$ eight each in $2015,{ }^{28} 2016,{ }^{29}$ and $2017,{ }^{30}$ seven in 2018, ${ }^{31}$ and 10 in 2019. ${ }^{32}$ In addition, the proceedings of the AB have been increasing in complexity, thereby becoming more laborious. ${ }^{33}$ Disputes have also become more sophisticated and legalistic, ${ }^{34}$ with some requiring the valuation of very technical evidence and involving multiple parties. ${ }^{35}$ 
The human and legal resources of the $\mathrm{AB}$ are manifestly inadequate to meet its current workload. Therefore, it is unsurprising that $\mathrm{AB}$ members were struggling to submit their reports ahead of deadlines. ${ }^{36}$ Heavy workload, the growing complexity of disputes, and part-time job basis make the $\mathrm{AB}$ members hard to complete their work on time. Indeed, such severe timeframes are unheard of in other international tribunals and courts. ${ }^{37}$ The 90 -day limit has been thus criticized as exceedingly short and onerous for both disputing parties and adjudicators. ${ }^{38}$ Some critics even argue that such time restrictions are simply no longer feasible. ${ }^{39}$ Without expanding the number of members and moving them to full-time employment, it is unreasonable to expect them to submit reports on time.

\section{The politicized selection of the $A B$ members}

As the $\mathrm{AB}$ has gradually established its status as an authoritative and capable adjudicator of complex and sensitive disputes, member states have attempted to exert control over the ideologies of individual $\mathrm{AB}$ members through the appointment procedure. ${ }^{40}$ Politicization is partly driven by some of the $\mathrm{AB}$ member states, especially the US, who have exerted control over the ideology of the AB by the process of appointment. ${ }^{41}$

A built-in political element of the $\mathrm{AB}$ composition is the balance of geographical distribution: a newly appointed member is generally expected to come from the same area as the outgoing member. ${ }^{42}$ In practice, however, members have demanded more. For example, the European Union (EU) threatened to block the selection of the $\mathrm{AB}$ members if their request for two seats in the $\mathrm{AB}$ was not granted. ${ }^{43}$

In the selection processes between 2013 and 2016, the WTO members frequently exercised or threatened to exercise their veto, pushing processes into a virtual log-jam. For example, the US rejection of reappointments in 2016 and its prolonged blockage of the launch of selection processes since 2017 mark a new peak in politicization.

Po-Ching Lee pessimistically claims that the politicization of the AB selection would not be stopped, let alone reversed, even if the present impasse were solved, and that the escalating demand for the $\mathrm{AB}$ seats will lead to more reckless and unscrupulous strategies from the WTO members, in particular when some have demonstrated how fragile the mechanism can be. ${ }^{44}$ 


\section{Short-term Nature of the WTO Members' Practices and Proposals}

To resolve the impasse in the AB, many WTO members, including the EU, Canada, Australia, and China, have seriously pursued a number of proposals. Moreover, academics working around the world have proposed various measures to resolve the deadlock. These proposals, which are discussed below, include, for example, eliminating the second stage of review, instituting majority voting to appoint $\mathrm{AB}$ members, and applying appeal arbitration under Article 25 of the DSU. Such measures would significantly change the dispute settlement system in use today. However, most of the proposals and practices are not long-term solutions. Although some WTO members now practice the appeal-arbitration approach, it is a "temporary avenue to enable appeals of penal reports," permanent solution is therefore necessary. Another approach, the implementation of a separate system for trade remedies could draw from experiences of the current crisis of the WTO dispute settlement mechanism when establishing a megamultilateral court. Before the examining the establishment of a mega-multilateral court, the flaws of current interim proposals shall first be identified below.

\section{Eliminating the second stage of review}

Eliminating the second stage of review would make the dispute end at the panel report. This approach has been used in one case, Indonesia-Iron or Steel Products (Viet Nam) (DS496). ${ }^{46}$ In this case, Indonesia and Vietnam would simply accept the first-stage panel report without appealing if the AB could not function. ${ }^{47}$ Simon Lester has said that this kind of agreement between parties to a dispute is one way that the WTO dispute settlement can continue to function if the $A B$ crisis is not resolved. ${ }^{48}$ Although this method allows the DSB to adopt the panel ruling, it presents several issues.

As this method makes panels the sole adjudicators during the DSM, this method effectively takes away the WTO members' right to appeal, as granted by the DSU. Moreover, applying only the first-stage panel report would reduce the quality of the adjudication system, since the $\mathrm{AB}$ cannot play its role of rectifying the panel's mistakes. ${ }^{49}$ Although Luiz E. Salles argues that this method would significantly reduce costs for parties (especially developing countries), lead to faster resolution of disputes, and shorten WTO dispute-settlement timeframes, ${ }^{50}$ the savings in cost, time, and effort would be offset by the disadvantages. ${ }^{51}$ 


\section{Majority voting, rather than consensus, to appoint the $A B$ members}

The Marrakesh Agreement allows for voting when consensus is not possible, ${ }^{52}$ although this is "very exceptional" in the WTO ${ }^{53}$ Because the US has been blocking the appointment of the $\mathrm{AB}$ members, majority voting becomes a feasible approach. Resolving the deadlock through the direct appointment of new $\mathrm{AB}$ members using majority voting, in either the General Council or the DSB, is regarded as "the nuclear option." ${ }^{54}$ Moreover, P.J. Kuijper agrees with the solution of majority voting because it permits an exact application of "emergency measures" and keeps the $\mathrm{AB}$ anchored inside the WTO. ${ }^{55}$ However, this approach has a number of limitations.

First, there is a concern that instituting voting for the appointment of the $\mathrm{AB}$ members may give the US an excuse to leave the WTO, ${ }^{56}$ which would probably happen for the first time when the US was outvoted. Second, one reason for the WTO's continued existence is that the members agree to operate by collective compromise, ${ }^{57}$ an agreement that majority voting may weaken or destroy. Third, this approach may be not well-received by the WTO members because they may fear that voting on the $\mathrm{AB}$ membership could set a worrying precedent for decisionmaking in other areas. ${ }^{58}$ For example, a previous suggestion in 1999 to vote on the issue of the selection of a new Director-General was poorly received, especially by the developed countries. ${ }^{59}$ Moreover, if an issue is resolved by majority voting today, other issues are expected to be similarly resolved tomorrow. ${ }^{60}$

It has caused some concern that the appointment of the $\mathrm{AB}$ members by voting may alienate the US, ${ }^{61}$ potentially causing it to withdraw from the WTO entirely, and would break the WTO's long-standing consensus tradition. ${ }^{62}$ However, voting could be applied on a flexible basis in selected cases, which is also consistent with the general institutional practice of international adjudicatory bodies. For example, the election of the International Tribunal for the Law of the Sea (ITLOS) is through majority voting. Therefore, it is possible that majority voting may be used for establishing a new mega-multilateral court according to the decision of State Parties, which could prevent the US from vetoing its establishment.

\section{Appeal arbitration under Article 25 of the DSU}

The main idea of Article 25 of the DSU is appeal arbitration: using the existing rule of Article 25 to continue appeals through arbitration. ${ }^{63}$ The parties to a dispute 
would agree to: arbitrate any appeal before the panel ruling is known; ${ }^{64}$ abide by the arbitration award through accepting a set of procedural rules applicable to the arbitration process; and notify all members in advance of the arbitration. ${ }^{65}$ The arbitration award, including the final panel report, could be consistent with the full WTO-covered agreement and circulated to all WTO members who wish to see it. ${ }^{66}$ Therefore, the binding character of an arbitration award under Article 25 does not rely on any action by the DSB, such as adoption and approval, which is contrary to other dispute settlement proceedings, and only the DSB and the relevant WTO councils or committees need to be notified. ${ }^{67}$ The State Parties may also agree that other members may participate in an arbitration as third parties if they are notified in advance of the start of the proceedings. ${ }^{68}$

Bypassing the $\mathrm{AB}$ process and channel appeals through the arbitration proceeding under Article 25 of the DSU has several advantages: for example, this approach is already in the rules and could be adopted without the need for consensus among the WTO members. ${ }^{69}$ Moreover, many WTO members already view appeal arbitration under Article 25 as an interim measure.

However, it does have some limitations. First, it is uncertain whether both parties would agree to an appeal arbitration in a given dispute. According to Article 25, "resort to arbitration shall be subject to the mutual agreement of the parties," while members would have no guarantee that other members, particularly the US, would agree to the process in a given dispute, ${ }^{70}$ if one party disagrees to an appeal arbitration, the process cannot be applied. In other words, if a member has already won at the panel stage, why would it agree to arbitration at the risk of losing its victory ? $^{71}$ Second, this approach means giving up on the AB. Once disputes are submitted to appeal arbitration, the $\mathrm{AB}$ will no longer play its role. The WTO members would be unlikely to subsequently restore the $\mathrm{AB}$ and the binding two-stage process. In addition, appeal-arbitration, being handled by ad hoc arbitration panels, would not produce as consistent jurisprudence as the AB. ${ }^{72}$ Third, this approach has no mechanism for implementing decisions resulting from interim appellate reviews. ${ }^{73}$ Article 25 of the DSU only mentions that the parties should abide by the arbitration award, ${ }^{74}$ while it does not specify an enforcement mechanism if the members fail to do so. Moreover, this approach only mentions that "the award shall be notified, but not adopted by, the Dispute Settlement Board and to the Council or Commission of any relevant agreement"; 7 in other words, 
the arbitration award is independent of any action by the DSB. Thus, it may be outside the binding dispute settlement system. Although the rules provide that the arbitration award under Article 25 should be subject to the supervision of the DSB, it is unclear what the DSB can do to enforce an unadopted arbitration award. ${ }^{76}$

Currently, the appeal-arbitration approach under Article 25, which does not require a change to the DSU rules themselves, ${ }^{77}$ is already practiced by some WTO members, including the EU, Australia, Brazil, Canada, Switzerland, Singapore, and China, and it is impossible to stop them. However, this option is considered as a "temporary avenue to enable appeals of panel reports" ${ }^{, 78}$ - an interim measure ${ }^{79}$ - and has many limitations, as discussed above. If the AB cannot be "fully composed" and resumes its function in the end, a long-term and definitive solution is needed. In this case, the mega-multilateral court could be the solution.

Without the US's co-operation, due to the limitations of the $\mathrm{AB}$, the practices and proposals provided by other members are not long-term solutions. ${ }^{80}$ Considering those situations, it is hard for the $\mathrm{AB}$ to remain fully composed and resume its function in the future. In addition, the proposal for establishing an interim appeal-arbitration process by reference to Article 25 of the DSU is merely a temporary measure, ${ }^{81}$ even before keeping its drawbacks in mind. Establishing a new mega-multilateral court can, to some extent, avoid some of the shortcomings of the AB, circumvent the US's "hostage-taking" actions, respond to some claims advanced by the US, and ultimately attract the US and other members as participants. $^{82}$

\section{Establishing a New Mega-multilateral COURT WITHIN THE WTO?}

Considering the current dysfunction of the $\mathrm{AB}$, it is necessary to propose a new mechanism to replace the original $\mathrm{AB}$, which is aimed to preserve the DSM. The proposed new mechanism is to establish a court within the WTO maintaining a mega-multilateral orientation, which would be subject to oversight by the DSB. Former AB member Ricardo Ramirez-Hernandez also pointed out that plurilateral agreements might be an option for the WTO members. ${ }^{83}$ The megamultilateral court would replace the original $\mathrm{AB}$ as a new appellate mechanism, 
but in a multilateral forum. Moreover, the panel process would not be affected. ${ }^{84}$ It would be binding only on the signatories. In addition, it could create a specialized chamber that could hear appeals of trade remedies, and a general chamber that could hear other cases.

\section{A. The New-mega Multilateral Court Only for Binding on the Signatories}

Members of the WTO would be free to choose whether to join the mega-multilateral court or not, which only requires the participation of those members that accept its function. ${ }^{85}$ In addition, it can only decide on disputes between its participating members; ${ }^{86}$ if disputes were to involve at least one member that is not participating in the mega-multilateral court, the dispute could be decided by appeal arbitration under Article 25 of the DSU, as is currently the practice, or resort to the mechanism of their Regional Trade Agreement. In other words, the WTO members participating in the new mega-multilateral court would be restricted by judgements given by the mega multilateral court, while members who decide not to take part in the court will not be bound by these judgements.

\section{B. A Special Chamber for Trade Remedies under the New Mega-multilateral Court}

A special chamber for trade remedies would be operated as an appellate chamber under the mega-multilateral court to which State Parties that had agreed to participate could appeal on trade-remedy cases, while the panel process for trade remedies matters would not be affected. ${ }^{87}$ A general chamber under the megamultilateral court would be responsible for cases not relevant to trade remedies.

There are a number of reasons for creating a special chamber related to trade remedies. First, it is clear that half of all WTO dispute settlements have concerned trade-remedy cases, which include disputes involving anti-dumping, antisubsidies, safeguard measures and so on. ${ }^{88}$ Second, the establishment of the special chamber aims to address the US concerns with respect to: the AB's substantive interpretations in certain disputes pertaining to subsidies, antidumping, and countervailing duties; standards under the Technical Barriers to Trade Agreement; and safeguards considered to be "adding to or diminishing rights and obligations" of the WTO members. ${ }^{89}$ Creating a special chamber under the mega-multilateral court to hear only trade-remedy disputes can focus on these issues, giving 
reasonable interpretations that may satisfy all parties. ${ }^{90}$ Therefore, although other special chambers can be established if necessary, the establishment of a special chamber for trade remedies is the first priority.

Such special chambers are not unprecedented. In fact, the practice is wellembedded in other areas of international law. For example, there are chambers of summary procedure, as well as for fisheries disputes and marine environment disputes in the international law of the sea, which are to examine highly technical and legal issues that require a professional process of dispute settlement. ${ }^{91}$ In the context of the WTO DSM, Jennifer Hillman has also proposed a separate system for trade remedies, which involves creating a "special AB to hear only appeals of trade remedy decisions." quite a feasible idea and justified by precedent.

The total number of adjudicators in the special chamber would be, as in the $\mathrm{AB}$, at least seven, a majority of whom should have deep trade-remedy expertise, as matters of trade remedies require adjudicators who specialize in international as well as domestic law on trade remedies. The special chamber could similarly be staffed by a secretariat with expertise in trade-remedy law. ${ }^{93}$ The chamber would consist of three adjudicators to hear a particular appeal of a trade-remedy case, at least two of whom are trade-remedy experts. This could increase the likelihood of correct judgements. $^{94}$

As for the appointment of adjudicators hearing an appeal, the president of the chamber could be appointed by the president of the mega-multilateral court, while the other two adjudicators could be appointed by the appellate parties themselves within the existing adjudicators of the special chamber. ${ }^{95}$ This approach that one party has its own adjudicator of the special chamber could improve both parties' satisfaction with the judgements to a certain extent, as it could reduce their concerns about potential unfair judgements. This would be especially relevant to the US, which has expressed concerns about unfair judgements.

Decisions coming from the special chamber would be subject to the same reverse-consensus process of adoption by the DSB, and compliance with the decisions would similarly be subject to the oversight of the DSB under the current system (DSU Articles 21 and 22). ${ }^{96}$ The principle of reverse consensus differs from the principle of consensus in that it is an "auto-jurisdiction": adjudications or reports can be passed as long as one member agrees. ${ }^{97}$ Reverse consensus offers a 
number of benefits for the special chamber. First, it could improve the efficiency of dispute settlement and ensure the operation of the chamber, which would be likely to face opposition from hegemonic countries such as the US. It could also avoid blockage from other members, since this proposal could be implemented even if only one member were to agree. In this regard, more leverage is given to the judicial independence of the mega-multilateral court, which is essential for preserving its perceived legitimacy. Second, it could keep the WTO DSB from being overly influenced by the assembly of State Parties. In general, reports or adjudications of the special chamber would normally take effect automatically since the nature of reverse consensus are "auto-jurisdiction," so that it could minimize the influence of the will of State Parties and ensure the legal effect of judicial organs' judgements.

The advantages of creating a special chamber for trade remedies are obvious. First, the adjudicators have deep trade-remedy expertise, which would ensure the chamber's professionalism and improve the correctness of judgements. Second, because trade-remedy cases, which account for half of the WTO's appeal cases, would be heard separately from other cases, this approach of having two bodies splitting the workload would assist both bodies to more readily complete their work within the required time. ${ }^{98}$ Third, cases related to trade remedies have become political battlefields, involving many national policy issues. In this case, stronger party autonomy could be readily achieved through the special chamber, whereby the disputing parties would be empowered to appoint the adjudicators in their specific case. ${ }^{99}$ Therefore, those methods as establishing a special chamber, appointing adjudicators with expertise, ${ }^{100}$ and taking a series of measures in the future to strengthen party autonomy may be able to mitigate the influence of political factors.

\section{The Large Mega-multilateral Court}

The implementation of the mega-multilateral court would initially generate a burdensome caseload involving hundreds of pages of submissions ${ }^{101}$ and disputes' growing complexity. ${ }^{102}$ However, as a response to complaints being reported after the deadline, the mega-multilateral court could act upon the lessons gained from the experience of the $\mathrm{AB}$ in the past and enable adjudicators to handle appeals submitted by State Parties within the specified time through increasing the number 
of the court members. ${ }^{103}$

The human and legal resources of the $\mathrm{AB}$ are manifestly inadequate to meet its current workload. In response to the lessons of the AB's failure, the number of court adjudicators would be increased compared to the AB. This approach also appears in the practice of other international courts. For example, the International Court of Justice has 15 members, ${ }^{104}$ the International Criminal Court has 18 members, ${ }^{105}$ and the ITLOS has 21 members. ${ }^{106}$ It is arguable that more adjudicators could improve both the capacity for making judgements within the prescribed time and the accuracy of those judgements.

In the abstract, increasing the number of adjudicators of the new megamultilateral court could have several advantages. Most importantly, it would help to deal with the excessive caseload. Delays are likely to be dealt with by increasing the number of adjudicators, which is one of the major problems in the WTO dispute settlement system. ${ }^{107}$ First, the establishment of the separate special chamber on trade remedies would benefit the efficiency of the mega-multilateral court, as its function is to distribute the labor force and excessive workload. Second, judges in the mega-court would be seated on a full-time basis, which would potentially allow the adjudicators to finish their work within the time limit, whether the time remains at 90 days or is extended. ${ }^{108}$

\section{The Multilateral Nature of the Mega Court as a Long-term Strategy}

Legally speaking, this proposal is based on the already existing multilateralism that exists in the WTO trade rules such as the Agreement on Government Procurement and Civil Aircraft. ${ }^{109}$ These multilateral agreements are only binding on the signatories, because the WTO agreements have as their basis the statement: "Plurilateral Trade Agreements (the agreements and associated legal instruments included in Annex 4) are also part of this Agreement for those Members who have accepted them, and are binding on those Members. The Plurilateral Trade Agreements do not create either obligations or rights for Members that have not accepted them."

The DSU applies to these multilateral agreements. For example, it is applied in the Agreement on Government Procurement, which states: "where any Party considers that any benefit accruing to it, directly or indirectly, under this Agreement is being nullified or impeded, or that the attainment of any objective 
of this Agreement is being impeded ... it may, with a view to reaching a mutually satisfactory solution to the matter, have recourse to the provisions of the DSB." ${ }^{111}$ Thus, the DSU can also be applied to the new mechanism. In addition, the DSU clearly reaffirms its application to these multilateral agreements: ${ }^{12}$

\begin{abstract}
With respect to disputes arising under a covered agreement which is a Multilateral Trade Agreement, the term "Member" as used herein shall refer only to those Members that are parties to the relevant Multilateral Trade Agreement. Where the DSB administers the dispute settlement provisions of a Multilateral Trade Agreement, only those Members that are parties to that Agreement may participate in decisions or actions taken by the DSB with respect to that dispute. ${ }^{113}$
\end{abstract}

The WTO permits the multilateral court to be binding only on the signatories to the dispute, not on all members. ${ }^{114}$ Therefore, it is acceptable and reasonable to establish a new mega-multilateral court for those members that are ready to accept the jurisdiction of the court and to ensure its legal binding force. ${ }^{115}$ The US and other WTO members might not take part in the new mega-multilateral court at its outset. ${ }^{116}$ However, with the continuous participation of the State Parties, the expansion of the court's scale, and its reasonable internal design-for instance, creating a special chamber that can respond to the US's dissatisfaction with traderemedy cases-there is a strong possibility that eventually the non-participating members, including the US, will take part. ${ }^{117}$

\title{
IV. DSB as a Forum for the Mega-multilateral Court and State Parties
}

The DSB is a judicial body which is composed in a diplomatic manner composed of representatives of the WTO members that administers the dispute settlement system. It could serve as a forum for members who participate in the court through the creation of an annual meeting in which they could provide regular feedback to adjudicators of this court, with a view to construing institutional dialogues between the court and State Parties. ${ }^{118}$ As Hrischman has written, a dissatisfied member's "increasing disagreement" within the policies of the organization can simply reflect a deterioration of this system as a whole, with members publicly 
articulating their dissatisfaction and attempting to reform the organization from the inside. Such initiatives could also work as an institutional response to dissatisfied members. ${ }^{119}$ An annual meeting would be helpful to sustain the internal legitimacy of the WTO adjudication. ${ }^{120}$ However, it may threaten the judicial independence of the multilateral court, as Fukunaga warned, "the direct dialogue between the $\mathrm{AB}$ and WTO Members at the DSB meetings would risk blurring the separate roles of the judicial and political branches of the WTO." ${ }^{121}$ Therefore, measures are needed to balance judicial independence, accountability, and consistency.

\section{A. The Concept of Judicial Independence, Accountability, and Consistency}

The notion of judicial independence embraces the independence of both judges and the international courts and tribunals themselves as international organizations. ${ }^{122}$ It refers to a series of institutional features that enable judges to perform their decision-making role, or judicial function, "unconstrained by the preferences" of other actors. ${ }^{123}$ In the domestic setting, judicial independence is mainly seen as freedom from the control of other departments of the government, while in the international sphere, it is concentrating on tribunals' freedom from control by State Parties. ${ }^{124}$ In practice, judicial independence is balanced and relative rather than absolute against other competing interests that include control by, and responsiveness to the concerns of, member states, which is helpful in maintaining State Parties' willingness to support international tribunals. ${ }^{125}$ Therefore, judicial independence not only is an inherent characteristic of judicial institutions, but also conforms to the common interest of State Parties. ${ }^{126}$

Judicial accountability, which also applies to both individual judges and courts or tribunals, is to some extent the other side of the coin to judicial independence. ${ }^{127}$ It can be defined as the cost that judges expect to incur if their behaviour or decisions deviate too much from a generally recognized standard; in this case, the letter of the law. ${ }^{128}$ The exact meaning of judicial accountability under the DSB is a tribunal's accountability to State Parties when acting through the political institution responsible for governing the tribunal. ${ }^{129}$ For instance, State Parties could express their opinions on the jurisprudence of courts and tribunals that address systemic issues when participating in the annual meeting between the mega-multilateral court and State Parties. ${ }^{130}$ The judicial bodies may respond to their concerns and interact with State Parties through the DSB. Such practice is a 
reflection of judicial accountability.

Consistency emphasizes the predictability of judicial decisions. International tribunals or courts would normally follow their precedents, unless there are cogent reasons to depart from them. In other words, when different cases present similar situations, courts and tribunals treat them in the same way. The development of international law and the establishment of a new mega-multilateral court would raise the question of whether the consistency of judicial decisions will be affected. This will be discussed below.

\section{B. Creating an Annual Meeting between the State Parties and Adjudicators of the Mega-multilateral Court under the DSB}

One way to allow the DSB to serve as a forum and to ensure judicial consistency as far as possible is to create an annual meeting between the mega-multilateral court and the DSB, in which any members who participate in the court could express their opinions on the reports it adopts. ${ }^{131}$ This goes beyond the existing right to express views at the time of a report's adoption. ${ }^{132}$ This idea of an annual meeting is somewhat similar to a proposal made by the Sutherland Report in 2004 that the DSB may play a more constructive role with regard to criticisms of the WTO jurisprudence. ${ }^{133}$ Furthermore, the relationship between a mega-multilateral court and the DSB may arise in other international legal contexts-specifically, the relationship between international tribunals and the political bodies responsible for overseeing their governance. ${ }^{134}$ Other international courts and tribunals have applied the approach of a regular meeting that enables informal dialogue between the political representatives of State Parties and adjudicators in the tribunals. For example, the ICJ, the ICC, and the ITLOS all provide annual reports to their governing political organs. The ICC also has a procedure for regular "diplomatic briefings" in which the President of the Court, Prosecutor and Registrar inform the representatives of State Parties about recent developments and there is an exchange of views. ${ }^{135}$

Creating an annual meeting would serve to institute a "communication link" where members of the court could voice their concerns with regard to systemic issues, judgements, focus of future judgements, trends in jurisprudence, and so on, in a manner unrelated to the adoption of particular reports. ${ }^{136}$ State Parties of the court could have more opportunities to provide feedback to the mega-multilateral 
court, and to exert informal political influence over the mega-multilateral court. ${ }^{137}$ In this way, the annual meeting, operated under the DSB, could improve the satisfaction of State Parties to a certain extent by giving them a means of expressing feedback and by improving the court's judicial accountability. ${ }^{138}$

In the context of the WTO, the option exists to convene a special session of the Dispute Settlement System to discuss particular issues. There is not much difference between the current mechanism and the proposal of creating an annual meeting; the main difference is that the annual meeting would include adjudicators of the multilateral court, which would increase dialogue, and thus common understanding, between them and State Parties of the mega-multilateral court. The crystallization of such common understanding can be understood as jurisprudence constante, which could benefit the consistency and coherence of judicial decisions. ${ }^{139}$ Moreover, the proposal of creating an annual meeting under the DSB as a replacement for existing meetings should enable consistency and protect both judicial independence and accountability to State Parties, as explained below.

\section{Balance between Judicial Independence, Accountability, and Consistency}

State Parties could potentially consider judgements of the mega-multilateral court to be in error. In such cases, an annual meeting would allow the State Parties and the members of the mega-multilateral court to reach a consensus to a certain extent. The proposal of creating an annual meeting could increase accountability by fostering dialogue between the State Parties and the adjudicators. However, it should be noted that such dialogue may also undermine and threaten judicial independence, as it gives the WTO members more influence over the judicial activities within the DSM. As Ratio Juris described, "judicial independence and judicial accountability seem to pull in opposite directions." ${ }^{140}$ If a judge is completely independent, there is a lack of accountability, but a completely accountable judge may feel pressured to rule in ways that please those to whom the judge is accountable. ${ }^{141}$ However, these two notions are potentially reconcilable and the crystallization of jurisprudence constante is still possible.

Consistency is a desirable quality in any legal system, including the proposed mega-multilateral court, which enables a sufficient degree of clarity, continuity, and permanence. ${ }^{142}$ Therefore, it is necessary to focus on the jurisprudence constante, which is helpful in achieving consistency of judicial decisions. 
How can an annual meeting then balance judicial independence, accountability, and consistency? At the outset, the annual meeting should not interfere with the ongoing proceedings of the mega-multilateral court. State Parties and members of the court should focus on the cases that have occurred and judgements that have already been made so as to make interpretative statements at the annual meeting. To be constructive and not undermine judicial independence, the interaction would need for the State Parties and members of the mega-multilateral court to focus on the refinement of particular questions of the WTO law, on a prospective basis, rather than on criticism of the mega-multilateral court itself. ${ }^{143}$ Such a process of interaction should not be allowed to interfere with the binding nature of reports made by the court in specific cases, to ensure judicial independence. ${ }^{144}$

Moreover, controversial issues may arise in the future, whereby legally uncertain issues could remit to the annual meeting for further negotiations and resolution in the political forum. ${ }^{145}$ In the same vein, discussion of such interpretative statements, which point to prospective legal issues that may arise in specific cases, should not be permitted when the respective judgements are in process or reports not yet submitted, which would unduly undermine judicial independence. ${ }^{146}$

Third, the written statements made by DSB between the State Parties and the court could be considered as jurisprudence constante to ensure the consistency of the mega-multilateral court. Members of the multilateral court could improve the content of the WTO law on a prospective basis, in an approach that is detached from the result in specific disputes. ${ }^{147}$ Members could discuss the interpretation of the mega-multilateral court through the process of interaction, and create a procedure for publishing and circulating discussions via the DSB statements on particular interpretative questions. ${ }^{148}$ The DSB statement would thus be more likely to be accepted and preferable as an interpretative declaration in writing and in formal circulation, as it would likely have a clearer legal status and be more precise than other types of statements. ${ }^{149}$ Members' statements could be collected and annotated by the Secretariat, and the DSB's written statements could be submitted as a report by a special expert group under the DSB after an agreement was reached between State Parties and the multilateral court. The authoritative interpretations crystallized through such institutional dialogues could have a significant effect on consistency for the members of the mega-multilateral court and panels in future cases. ${ }^{150}$ Such a practice follows the suggestion of Peter 
Sutherland, who advocates "occasionally selecting particular adjudicatory findings for in-depth analysis by a reasonably impartial through a special expert group of the DSB, the purpose of which is to provide a measured report of constructive criticism for the information of the WTO system, including the AB and panels." ${ }^{151}$ In this way, a consensus may be reached on particular interpretative questions between the State Parties and members of the mega-multilateral court, and the support for existing interpretative statements could be registered by members of State Parties, even if some interpretations might not gain sufficient support to constitute a subsequent agreement or practice, or to enable the adoption of authoritative interpretations or amendments. ${ }^{152}$ Thus, interpretative statements that contribute to an agreement in the reports between State Parties and members of the multilateral court could be regarded as jurisprudence constante, which would ensure the consistency of the multilateral court.

Fourth, although the maintenance of jurisprudence is highly desirable, judicial decisions could depart from it if there were cogent reasons, which would prevent the mechanical application of consistency in judicial proceedings. The concept of "cogent reasons" is defined by the Penal Report of US-Countervailing and AntiDumping Measures (China):

(i): agreements under Article IX:2 of the WTO Agreement that departs from a prior $\mathrm{AB}$ interpretation; (ii) a demonstration that a prior $\mathrm{AB}$ interpretation proven to be unworkable in a particular set of circumstances failing within the scope of the relevant obligation at issue; (iii) a demonstration that the AB's prior interpretation leads to a conflict with another provision of a covered agreement that was not raised before the $\mathrm{AB}$; or (iv) a demonstration that the $\mathrm{AB}$ 's interpretation was based on a factually incorrect premise. ${ }^{153}$

The definition of "cogent reasons" can be interpreted differently by different tribunals and courts. It is unrealistic to define all its meanings, given the jurisprudential traditions and variety of institutional settings, coupled with the varying structures of international courts. It is therefore practical to flesh out the bones of "cogent reasons" based on the development of international law, the judicial practice of the mega-multilateral court, and the institutional interactions between State parties and members of the court. ${ }^{154}$

The DSB could be a bridge or link to ensure the interaction between State Parties 
and the mega-multilateral court by creating an annual meeting. To try to balance the court's judicial independence, accountability to State Parties, and consistency, even the measures explained above may not be enough. ${ }^{155}$ As Blokker has suggested, it is hard to design procedures that enable meaningful dialogue between international tribunals and State Parties, and that strike an appropriate balance between judicial accountability to and judicial independence from State Parties. ${ }^{156}$ Thus, there is no panacea that balances judicial independence, accountability, and consistency. However, detailed rules and procedures to accomplish these sometimes-conflicting goals could be developed under international law.

\section{Conclusion}

The current crisis over the appointment of the $\mathrm{AB}$ members has already prevented the continued operation of the WTO's compulsory and binding disputesettlement mechanism. Approaches provided by other WTO members aimed at circumventing the "hostage-taking" actions of the US are both legally fragile and of an interim nature only, particularly given the non-cooperation of the US and the current limitations of the $\mathrm{AB}$. In this light, a new mega-multilateral court could be a long-term solution to the need for legal certainty and judicial credibility for global trade.

Although the new mega-multilateral court would only be binding on the signatories, and not all members of the WTO would participate in it immediately, the court would not only serve to settle disputes in the long run, but also inevitably guide the development of rules and principles of the WTO DSM, if the number of signatories is sufficient to ensure the subsistence of compulsory dispute settlement among those members. ${ }^{157}$ A system accepted as authoritative by a majority of the membership would likely have important effects on the evolution of the WTO legal regime, even if it does not bind all members. ${ }^{158}$ If members such as the US still refuses to join the new system, they might have an increasing incentive to engage with the court when they are confronted with pronouncements and determinations of the court that are considered authoritative interpretations of the WTO rights and obligations.

Other proposals, such as creating a special chamber for trade remedies and 
changes to the appointment of members, are only preliminary ideas that require further and more-detailed thinking if the mega-multilateral court is implemented in the future. Furthermore, the DSB could serve as a forum through the creation of an annual meeting between adjudicators and State Parties of the mega-multilateral court, and maintain the balance between judicial independence, accountability, and consistency in the meantime.

\section{REFERENCES}

1. Qingjiang Kong \& Shuai Guo, Towards a Mega-Plurilatera Dispute Settlement Mechanism for the WTO? 53 J. WORLD TRADE 273 (2019).

2. US Mission to International Organizations in Geneva (June 22 2018), Statements by the United States at the Meeting of the WTO Dispute Settlement Body, available at https:// geneva.usmission.gov/2018/06/22/statements-by-the-united-states-at-the-june-22-2018dsb-meeting.

3. Id.

4. Dispute Settlement Body, Minutes of Meeting, $\uparrow \uparrow$ 4.19-4.20, WTO Doc. WT/DSB/M/420 (Feb. 27, 2019).

5. Id. at $94.20-4.25$.

6. DSU art. 17(6).

7. Dispute Settlement Body, Minutes of Meeting, ๆๆ 4.20-4.25, WTO Doc. WT/DSB/M/423 (Apr. 4, 2019).

8. Supra note 1, at 273.

9. P. Bhattacharya, WTO Members Stress Rule-based Multilateral Trading System, DAILY STAR, Mar. 22, 2018, available at https://www.thedailystar.net/business/wto-membersstress-rule-basedmultilateral-trading-system-1551562.

10. P. Kuijper, From the Board: The US Attack on the WTO Appellate Body 45 LEGAL IssueS ECON. INTEGRATION 1-11 (2018).

11. Supra note 1 , at 273.

12. Communication from Japan, Australia and Chile, Informal Process on Matters Related to the Functioning of the Appellate Body, 2.2, WTO Doc. WT/GC/W/768/Rev.1 (Apr. 25, 2019).

13. J. Hillman, Reforming the WTO through the Prism of Rules-versus Power-based Trade Relations, American Society of International Law 2020 Virtual Annual Meeting (June 25, 2020), available at https://www.asil.org/events/reforming-wto-through-prism-rules- 
versus-power-based-trade-relations.

14. J. Pauwelyn \& R. Hamilton, Exit from International Tribunals 9 J. InT'L DisP. SETTLEMENT 687 (2018).

15. R. McDougall, The Crisis in WTO Dispute Settlement: Fixing Birth Defects to Restore Balance 52 J. World TRAde 867 (2018).

16. G. Shaffer, A Tragedy in the Making? The Decline of Law and the Return of Power in International Trade Relations, 37 YaLE J. INT'L L. 42-46 (2018).

17. US Mission to International Organizations in Geneva Statement by the United States at the Meeting of the WTO Dispute Settlement Body, (Sep. 30, 2019), available at https:// geneva.usmission.gov/2019/10/01/statements-by-the-united-states-at-the-september-302019-dsb-meeting.

18. T. Stewart, Disputed Court: A Look at the Challenges to (and from) the WTO Dispute Settlement System, Global Business Dialogue (Dec. 20, 2017), available at http://events. r20.constantcontact.com/register/event?1lr=byq9v7bab\&oeidk=a07eex37w3143103230.

19. Y. Fukunaga, Interpretative Authority of the Appellate Body: Replies to the Criticism by the United States, Social Science Research Network (Mar. 20, 2019), available at https:// papers.ssrn.com/sol3/papers.cfm?abstract_id=3356134.

20. F. Simões, Should Appellate Body Members Work Full Time?, in The Appellate Body of THE WTO And Its Reform 273 (C. Lo \& J. Nakagawa \& T. Chen eds., 2020).

21. Id. at 274.

22. Appellate Body Annual Report, $\uparrow 13$, WTO Doc. WT/AB/28 (June 2, 2018).

23. Id. ๆ 4, WTO Doc. WT/AB/15 (July 18, 2011).

24. Id. 6, WTO Doc. WT/AB/17 (June 13, 2012).

25. Id. 112 , WTO Doc. WT/AB/18 (Apr. 9, 2013).

26. Id. ๆ 12, WTO Doc. WT/AB/20 (Mar. 14, 2014).

27. Id. 111 , WTO Doc. WT/AB/24 (July 3, 2015).

28. Id. 12 , WTO Doc. WT/AB/26 (June 3, 2016).

29. Id. ๆ 15, WTO Doc. WT/AB/27 (May 16, 2017).

30. Supra note 22.

31. Appellate Body Annual Report, $\uparrow 13$, WTO Doc. WT/AB/29 (May. 28, 2019).

32. Id. ๆ 15, WTO Doc. WT/AB/30 (July 31, 2020).

33. Supra note 20, at 275.

34. Id. at 274.

35. V. Hughes, The Strengths, Weaknesses, and Future of WTO Appellate Review, in THE WTO: Governance, Dispute Settlement \& Developing Countries 378 (E. Janow \& V. Donaldson \& A. Yanovich eds., 2008).

36. Supra note 20, at 275.

37. Id. at 277.

38. UNCTAD, Dispute Settlement: World Trade Organization 3.1 Overview (Jan. 20, 2000), 
available at http://unctad.org/en/docs/ edmmisc232add11_en.pdf.

39. Supra note 20, at 274.

40. P. Lee, Appointment and Reappointment of the Appellate Body Members: Judiciary or Politics, in The Appellate Body of the WTO and Its Reform 255 (C. Lo \& J. Nakagawa \& T. Chen eds., 2020).

41. Id. at 256.

42. Id.

43. D. Steger, The founding of the Appellate Body, in A History of LAW And Lawyers IN THE GATT/WTO 449-50 (G. Marceau ed., 2015).

44. Supra note 40, at 255.

45. S. Andersen, Using Arbitration under Article 25 of the DS to Ensure the Availability of Appeals, 17 Centre Trade \& Econ. Integration 2 (2017).

46. Panel Report, Indonesia - Safeguard on Certain Iron or Steel Products, WTO Doc. WT/ DS496/R, available at https://www.wto.org/english/tratop_e/dispu_e/cases_e/ds496_ e.htm; Communication from Indonesia, Indonesia - Safeguard on Certain Iron or Steel Products, WTO Doc. WT/DS90/14 WT/DS496/15 (Apr. 16, 2019).

47. Id.

48. P. Ungphakorn, A bit of bother down at the WTO court-Why? And is it a killer? Long read, Trade $\beta$ Blog (Aug. 21, 2019), available at https://tradebetablog.wordpress.com/ 2019/08/21/bother-at-wto-court.

49. Id.

50. L. Salles, Guest Post on Bilateral Agreements as an Option to Living through the WTO AB Crisis, International Economic Law and Policy Blog (Nov. 23, 2017), available at https://worldtradelaw.typepad.com/ielpblog/2017/11/guest-post-on-bilateral-agreementsas-an-option-to-living-through-the-wto-ab-crisis.html.

51. G. Deepak, WTO dispute settlement-the road ahead, 51 N.Y.U. J. INT'L L. \& PoL. 991-2 (2019).

52. Marrakesh Agreement 1994 art. 9(1).

53. A. Raina, Meditations in an Emergency: The Appellate Body Deadlock- What It Is, Why It Is a Problem, and What to Do About It, 13 Global Trade \& Customs J. 13 (2018).

54. Global Governance Centre, Deadlock at the WTO: Pathways to Maintaining an Effective System for Appellate Review (Nov. 30, 2017), available at https://graduateinstitute.ch/ communications/news/deadlock-wto-pathways-maintaining-effective-system-appellatereview.

55. Supra note 10 , at 8.

56. Supra note 51, at 992-3.

57. Supra note 53, at 13-4.

58. Supra note 51, at 992-3.

59. Id. 
60. Id.

61. R. McDougall, The Search for Solutions to Save the WTO Appellate Body, 3 Eur. CEnTRE INT'L PoL. ECON. 2 (2017).

62. Supra note 53, at 14.

63. J. Hillman, Three approaches to fixing the world trade organization's appellate body: the good, the bad and the ugly? Georgetown Law Center (Dec. 12, 2018), available at https://www.law.georgetown.edu/wp-content/uploads/2018/12/Hillman-Good-Bad-UglyFix-to-WTO-AB.pdf.

64. DSU art. 25(2) \& (3).

65. P. Bossche \& W. Zdouc, The Law and Policy of the World Trade Organization: Text, Cases and Materials 187 (2005).

66. DSU art. 25(3).

67. Supra note 45 , at 17.

68. Supra note 65 , at 56 .

69. Supra note 63 , at 8.

70. Id.

71. R. Sharma, WTO Appellate Body at Cross Roads: Options and Alternatives, in THE Appellate Body of the WTO and Its Reform 249 (C. Lo \& J. Nakagawa \& T. Chen eds., 2020).

72. Id.

73. Id. at 250 .

74. DSU art. 25(3).

75. Id.

76. Supra note 71, at 251.

77. Supra note 63 , at 9.

78. Supra note 45, at 17.

79. European Commission, Trade: EU and 16 WTO Members Agree to Work Together on an Interim Appeal Arbitration Arrangement, Press Release, Jan. 24, 2020, available at https://ec.europa.eu/commission/commissioners/2019-2024/hogan/announcements/tradeeu-and-16-wto-members-agree-work-together-interim-appeal-arbitration-arrangement en.

80. From a political perspective, any solution that is worked out should be demonstrating that the rest of the world is hearing what the US is saying - even if they don't always agree with the US' claims. See supra note 63, at 4.

81. Supra note 45 , at 17.

82. Supra note 1 , at 284.

83. R. Ramirez-Hernandez, Farewell Speech of Appellate Body Member Ricardo RamírezHernández, International Economic Law \& Policy Blog (May 15, 2018), available at https://ielp.worldtradelaw.net/2018/05/farewell-speech-of-appellate-body-member- 
ricardo-ram\%C3\%ADrez-hern\%C3\%A1ndez.html.

84. Supra note 1, at 280-1.

85. Id.

86. Id.

87. Id.

88. Supra note 63 , at 6.

89. USTR, 2018 Trade Policy Agenda and 2017 Annual Report of the President of the United States on the Trade Agreements Program (Mar. 2018), available at https:/ustr.gov/sites/ default/files/files/Press/Reports/2018/AR/2018\%20Annual\%20Report\%20FINAL.PDF.

90. Supra note 63, at 6 .

91. For the comprehensive analysis on the working method of the ITLOS, see generally P. Rao \& P. Gautier, The International Tribunal for the Sea: Law Practice and Procedure (2018). For the analysis on the settlement of marine environmental disputes and the role of special chamber, see Ke Song, Note on the Resolution on the Chamber for Marine Environment Disputes, in Oxford International Organizations (J. Aspremont \& C. Brölmann eds., 2019).

92. Supra note 63, at 6.

93. Id.

94. Id.

95. In UNCLOS dispute settlement procedures, the president of the ITLOS may appoint the arbitrators of the Annex VII arbitral tribunals. See UNCLOS annex VII art. 3(b) \& 3(c). In practice, such appointment procedure could eventually promote consistency and coherence of jurisprudence, as members of courts and tribunals substantially overlap in addition, appellate parties could appoint their own adjudicators, which might improve the possibility of fair judgements.

96. Supra note 63, at 6.

97. Supra note 63, at 6. See also GATT arts. 6(1) \& 16(4) \& 17(14) \& 22(6).

98. Id.

99. Id.

100. Id. at 4 .

101. V. Hughes, The Institutional Dimension, 10 The Oxford Handbook of International Trade Law 282 (2009).

102. Supra note 20, at 274.

103. G. Sacerdoti, The WTO Dispute Settlement System: Consolidating Success and Confronting New Challenges, in Assessing the World Trade Organization: Fit for Purpose? 147-74 (M. Elsig \& B. Hoekman \& J. Pauwelyn eds., 2017).

104. I.C.J. Statute art. 3(1).

105. ICC Statute art. 36(1).

106. ITLOS Statute art. 2(1). 
107. Supra note 20, at 276.

108. Id. at 279.

109. WTO Agreement on Trade in Civil Aircraft, 1869 UNTS 508 (Civil Aircraft Agreement) \& WTO Agreement on Government Procurement, 1869 UNTS 508 (GPA).

110. WTO Agreement art. 2, $\mid 3$.

111. Agreement on Government Procurement art. 20, $\llbracket 2$. See also supra note 1, at 285.

112. Supra note 1, at 282.

113. $I d$.

114. Id. at 286.

115. Id.

116. Supra note 10, at 9.

117. G. Vidigal, Living Without the Appellate Body: Multilateral, Bilateral and Plurilateral Solutions to the WTO Dispute Settlement Crisis, 20 J. World Inv. \& Trade 890 (2019).

118. Id.

119. A. Hirschman, Exit, Voice and Loyalty: Responses To Decline in Firms, Organizations, and States 106 (1970).

120. Id.

121. Y. Fukunaga, The Appellate Body's Power to Interpret the WTO Agreements and WTO Members' Power to Disagree with the Appellate Body, 20 J. World Inv. \& TRAde 818 (2019).

122. R. Mckenzie, International Courts and Tribunals and the Independence of the International Judge, 44 HARV. INT'L L. J. 271-85 (2003).

123. J. Paine, The WTO's Dispute Settlement Body as a Voice Mechanism, 20 J. World Inv. \& TRADE 820-61 (2019).

124. Id. at 834 .

125. Id.

126. N. Blokker, The Governmence of International Courts and Tribunals: Organizing and Guaranteeing Independence and Accountability, in THE JUDICALIZATION OF INTERNATIONAL LAw 36-37 (A. Follesdal \& G. Ulfstein eds., 2018).

127. Supra note 123 , at 835 .

128. The Accountability of the Judiciary, Law Teacher Net (Aug. 15, 2019), available at https://www.lawteacher.net/free-law-essays/constitutional-law/the-accountability-ofthe-judiciary-constitutional-law-essay.php.

129. Supra note 123 , at 835 .

130. Id.

131. Id.

132. Id.

133. T. Zimmermann, Book Review: The Future of the WTO: Addressing Institutional Challenges in the New Millennium, 60 AussenwirTsCHat 241 (2005). 
134. Supra note 126 , at 36 .

135. Id. at 39-40.

136. Communication from Honduras, Fostering A Discussion on the Functioning of the Appellate Body, WTO Doc. WT/GC/W/759 (Jan. 21, 2019).

137. Id.

138. Supra note 123 , at 851.

139. P. Sutherland et al., The future of the WTO: Addressing Institutional Challenges in the New Millennium, 1250 (WTO, 2004), available at https://eldis.org/document/A17976.

140. R. Juris, Judicial Independence v. Judicial Accountability: Prolegomenon to Defining Constitutionalism in the Fourth Century of the American Experiment, Ratio Juris's blog (Feb. 9, 2007), available at http://ratiojuris.blogspot.com/2007/02/judicial-independence-vjudicial.html.

141. Id.

142. G. Guillaume, The Use of Precedent by International Judges and Arbitrators, 2 J. INT'L. Disp. SettLement 5-23 (2011).

143. C. Ehlermann \& L. Ehring, The Authoritative Interpretation Under Article IX:2 of the Agreement Establishing the World Trade Organization: Current Law, Practice and Possible Improvements, 8 J. INT'L Econ. L. 813-8 (2005).

144. Supra note 121, at 793-5 \& 812-8.

145. T. Payosova \& G. Hufbauer \& J. Schott, The Dispute Settlement Crisis in the World Trade Organization: Causes and Cures, Policy File (Mar. 1, 2018), available at https:// piie.com/system/files/documents/pb18-5.pdf.

146. Supra note 123 , at 836-8.

147. Id. at 858 .

148. Supra note 143 , at 812.

149. C. Creamer, From the WTO's Crown Jewel to Its Crown of Thorns, 113 Am. J. InT'L L. 51-4 (2019).

150. Supra note 133, at 241-2.

151. Id.

152. Supra note 143 , at $812-8$.

153. Penal Report, United States- Countervailing and Anti-Dumping Measures on Certain Products from China, 97.317 , WTO Doc. WT/DS449/R (Mar. 27, 2014).

154. See generally A. Elferink \& T. Henriksen \& S. Busch, Maritime Boundary Delimitation: The Case Law (1st ed. 2018).

155. Supra note 126, at 37-9.

156. Id. at 40.

157. Supra note 117 , at 890 .

158. Id. 
